\title{
YIELD OF INTERCROPPED LETTUCE AND CUCUMBER AS A FUNCTION OF POPULATION DENSITY AND CROPPING SEASON ${ }^{1}$
}

\author{
ARTHUR BERNARDES CECÍLIO FILHO ${ }^{2 *}$, BRAULIO LUCIANO ALVES REZENDE ${ }^{3}$, ALEXSON FILGUEIRAS \\ DUTRA $^{2}$
}

\begin{abstract}
The possibility of increasing vegetable production per unit area is one of the advantages of the intercropping system. However, there is a lack of information about the effect of climatic factors and the management of different species on the viability of this production system. To this end, four experiments were carried out to evaluate the yield of intercropped lettuce and cucumber as a function of cropping season, cucumber population density, and lettuce transplanting time. Each experiment was conducted in a randomized block design with nine treatments arranged in a $2 \times 4+1$ factorial scheme, corresponding to two cropping systems (intercropping and monoculture), four transplanting times of 'Lucy Brown' lettuce (0, 10, 20, and 30 days after cucumber transplanting), and 'Hokushin' cucumber monoculture. The experiments were carried out in two seasons (August to November and February to May) and with two cucumber population densities (1.1 and 2.2 plants $\mathrm{m}^{-2}$ ). Total and commercial cucumber yields were not influenced by the presence of lettuce. However, regardless of cropping season, the presence of cucumber affected lettuce yield, with later transplanting corresponding to greater negative impact. Lettuce intercropped with cucumber at a density of 2.2 plants $\mathrm{m}^{-2}$ and grown from February to May did not reach commercial quality. The greatest efficiency of lettuce and cucumber intercropping was obtained by transplanting the two species on the same day in August, with cucumber at a density of 1.1 plants $\mathrm{m}^{-2}$.
\end{abstract}

Keywords: Lactuca sativa L. Cucumis sativus L. Cropping systems. Transplanting time. Protected cultivation.

\section{PRODUTIVIDADE DO CONSÓRCIO DE ALFACE E PEPINO EM FUNÇÃO DA DENSIDADE POPULACIONAL E ÉPOCA DE CULTIVO}

\begin{abstract}
RESUMO - A possibilidade de aumentar a produção de hortaliças por unidade de área é uma das vantagens do sistema de cultivo consorciado. Porém, há escassez de informações sobre o efeito de fatores climáticos e do manejo das espécies consorciadas na viabilidade desse sistema de produção. Para tanto, quatro experimentos foram instalados objetivando-se avaliar a eficiência produtiva do consórcio de alface e pepino em decorrência da época de cultivo, densidade populacional do pepino e época de transplante da alface. Cada experimento foi conduzido em delineamento de blocos ao acaso com nove tratamentos, organizados em esquema fatorial $2 \times 4$ +1 , sendo dois sistemas de cultivo (consórcio e monocultura), quatro épocas de transplante da alface 'Lucy Brown' (0, 10, 20 e 30 dias após o transplante do pepino) e a monocultura de pepino 'Hokushin'. Os experimentos foram realizados em duas épocas (agosto a novembro e fevereiro a maio) e com duas densidades populacionais de pepino $\left(1,1\right.$ e 2,2 plantas $\left.\mathrm{m}^{-2}\right)$. As produtividades total e comercial de pepino não foram influenciadas pela presença da alface. Entretanto, independentemente da época de cultivo, a presença do pepino afetou o desempenho produtivo da alface, com maior prejuízo à medida que mais tardio foi seu transplante. A alface consorciada com pepino na densidade de 2,2 plantas $\mathrm{m}^{-2}$ e cultivado de fevereiro a maio não apresentou qualidade comercial. Maior eficiência da consorciação da alface e pepino é obtida com transplante das duas espécies no mesmo dia, em agosto, e densidade de 1,1 planta $\mathrm{m}^{-2}$ de pepino.
\end{abstract}

Palavras-chave: Lactuca sativa L. Cucumis sativus L. Sistemas de cultivo. Época de transplante. Cultivo protegido.

\footnotetext{
*Corresponding author

${ }^{1}$ Received for publication in $07 / 24 / 2019$; accepted in $09 / 13 / 2019$.

Paper extracted from the doctoral thesis of the second author.

${ }^{2}$ Department of Plant Production, Universidade Estadual Paulista 'Julio de Mesquita Filho', Jaboticabal, SP, Brazil; arthur.cecilio@unesp.br - ORCID: 0000-0002-6706-5496, alexsondutra@gmail.com - ORCID: 0000-0003-2837-5720.

${ }^{3}$ Instituto Federal de Educação, Ciência e Tecnologia do Sul de Minas, Muzambinho, MG, Brazil; blrezende76@gmail.com - ORCID: 0000-0001-9678-5778.
} 


\section{INTRODUCTION}

The intensity of modern agriculture involving large areas of monoculture impacts the environment, especially in terms of soil degradation and ecological imbalance (NASCIMENTO et al., 2018). Developing new technologies is thus fundamental to making modern agriculture a sustainable and productive activity. Intercropping is a technology that enables production with rational land use and less environmental impact. In addition, it is a technique with agroeconomic advantages over monoculture, as it allows greater efficiency in the use of water, soil, agricultural inputs, and labour, and helps increase the income from agricultural activity (CECÍLIO FILHO et al., 2011, 2017; GOU; VAN ITTERSUM; VAN DER WERF, 2017). It is also noteworthy that intercropping causes less impact on the environment due to greater biological diversity, rapid soil cover, and reduced planting area (WANG et al., 2014).

However, intercropping is a more complex production system than monoculture, as it is characterized by competition among coexisting species. The interaction of intercropped species promotes interspecific competition for resources such as water, light, solar radiation, and nutrients, in which one species can outcompete the other. To avoid or reduce this competition, managers should seek complementarity between intercropped species, thus promoting higher yield (BROOKER et al., 2015; CECÍLIO FILHO et al., 2017).

To obtain good results from intercropping, various production factors that have already been properly studied in monocultures need to be reevaluated. Even in cucumber and lettuce intercropping, which has proven agroeconomic viability (REZENDE et al., 2011), simply changing the cultivar (PORTO et al., 2011; CECÍLIO FILHO et al., 2015) or cropping season (CECÍLIO FILHO et al., 2011) can affect overall viability, including leading to total failure (REZENDE et al., 2010).

Cucumber and lettuce crops were chosen for this study because they are two of the most important vegetables and have distinct botanical and agronomic characteristics, which favour their intercropping as they allow for complementarity with each other (CECÍLIO FILHO et al., 2015, 2017). With a cycle lasting between 90 and 120 days and with plants trained vertically, cucumber favours the cultivation of other species among its rows. One example is lettuce, which is among the leafy vegetables most appreciated in gastronomy and represents an important source of income for farmers. Moreover, due to its small size and short cycle, lettuce has generally been used as a secondary crop in intercropping. In this sense, intercropping lettuce with crops such as garlic and cucumber (CAI et al., 2011; XIAO et al., 2013), tomato (CECÍLIO FILHO et al., 2011), and broccoli (OHSE et al., 2012) is possible due to the minimal interference with light radiation to lettuce plants, that is, minimal competition for light. However, cucumber population density will determine whether there is more or less lettuce shading, influencing its growth, yield, and, consequently, the agroeconomic viability of the intercropping system.

Therefore, this study evaluated the yield of intercropped 'Lucy Brown' lettuce and 'Hokushin' cucumber as a function of cropping season, cucumber population density, and lettuce transplanting time.

\section{MATERIAL AND METHODS}

The research was conducted in a greenhouse at Universidade Estadual Paulista, in Jaboticabal city, São Paulo State $\left(21^{\circ} 15^{\prime} 22^{\prime}\right.$ S, $48^{\circ} 15^{\prime} 58^{\prime \prime} \mathrm{W}$; $575 \mathrm{~m}$ altitude). The climate of the region is subtropical with summer rains and a relatively dry winter, with annual averages of $1424.6 \mathrm{~mm}, 22.3^{\circ} \mathrm{C}$, $29.1{ }^{\circ} \mathrm{C}$, and $16.9{ }^{\circ} \mathrm{C}$ for rainfall and mean, maximum, and minimum temperatures, respectively (ROLIM, 2019).

Four experiments were conducted, each with nine treatments and four replicates. For this, a randomized block design was used in a $2 \times 4+1$ factorial scheme, corresponding to two cropping systems (intercropping and monoculture), four lettuce transplanting times $(0,10,20$, and 30 days after cucumber transplanting), and cucumber monoculture. The four experiments differed according to the combination of cropping season (August to November 2005 and February to May 2006) and cucumber population density (1.1 and 2.2 plants $\mathrm{m}^{-2}$, corresponding to one and two cucumber rows in the bed, respectively) (Table 1). The experimental plot in each experiment measured 2.75 $\mathrm{m}^{2}(1.10 \times 2.50 \mathrm{~m})$ and all plants in the useful area $(1.10 \times 2.00 \mathrm{~m})$ were evaluated.

Table 1. Description of lettuce-cucumber intercropping system combined with cropping season and cucumber population density.

\begin{tabular}{cl}
\hline Experiment & \multicolumn{1}{c}{ Description } \\
\hline $1-2 \mathrm{R} 05$ & Two rows, August to November, 2005 \\
$2-1 \mathrm{R} 05$ & One row, August to November, 2005 \\
$3-2 \mathrm{R} 06$ & Two rows, February to May, 2006 \\
$4-1 \mathrm{R} 06$ & One row, February to May, 2006 \\
\hline
\end{tabular}


The soil in the area is classified as a very clayey Eutroferric Red Latosol (SANTOS et al., 2018). Soil samples collected at $0.2 \mathrm{~m}$ depth in the first and second cropping season were analyzed, with the following results respectively: $\mathrm{pH}\left(\mathrm{CaCl}_{2}\right): 6.2$ and 6.2; organic matter: 18 and $22 \mathrm{~g} \mathrm{dm}^{-3} ; \mathrm{P}_{(\text {resin) }}$ : 173 and $211 \mathrm{mg} \mathrm{dm}^{-3}$; K: 3.4 and $5.5 \mathrm{mmol}_{\mathrm{c}} \mathrm{dm}^{-3}$; Ca: 58 and $77 \mathrm{mmol}_{\mathrm{c}} \mathrm{dm}^{-3}$; $\mathrm{Mg}$ : 25 and $35 \mathrm{mmol}_{\mathrm{c}} \mathrm{dm}$ ${ }^{-3}$; B: 0.3 and $0.22 \mathrm{mg} \mathrm{dm}^{-3}$; Cu: 5.6 and $5.2 \mathrm{mg} \mathrm{dm}^{-3}$; Fe: 13.5 and $17.5 \mathrm{mg} \mathrm{dm}^{-3}$; Mn: 17.9 and $35.7 \mathrm{mg}$ $\mathrm{dm}^{-3}$; $\mathrm{Zn}: 2.4$ and $2.8 \mathrm{mg} \mathrm{dm}^{-3}$; and cation exchange capacity (CEC): 101.9 and $136.5 \mathrm{mmol}_{\mathrm{c}} \mathrm{dm}^{-3}$.

Liming was not performed in any of the cropping seasons, as $\mathrm{pH}$ and base saturation values were adequate. The intercropped plots and the cucumber monoculture were fertilized at planting following the recommendation of Trani et al. (1997), applying nitrogen $(\mathrm{N})$, phosphorus $(\mathrm{P})$, and potassium $(\mathrm{K})$ rates as recommended for cucumber, since it is the most demanding crop of the two. The lettuce monoculture was fertilized as recommended by Trani, Passos and Azevedo Filho (1997). Supplementary fertilization for lettuce and cucumber intercropping and monocultures was performed based on the recommendations of Trani, Passos and Azevedo Filho (1997) and Trani et al. (1997).

The seedlings of 'Hokushin' cucumber and 'Lucy Brown' lettuce were grown in polystyrene trays. Lettuce seedlings were transplanted to the bed at a spacing of $0.40 \times 0.35 \mathrm{~m}$ when presenting four leaves. Cucumber seedlings were transplanted when presenting an expanded leaf and emergence of the second leaf, following a spacing of $1.20 \times 0.60 \times$ $0.50 \mathrm{~m}$ for two cucumber rows in the bed (density of 2.2 plants $\mathrm{m}^{-2}$ ) and $1.80 \times 0.50 \mathrm{~m}$ for one cucumber row in the bed (density of 1.1 plants $\mathrm{m}^{-2}$ ).

Cucumber plants were trained vertically on a single stem and axillary branches up to the height of $0.40 \mathrm{~m}$ were removed. Buds in the upper nodes were allowed to grow and were then affixed to horizontally arranged wires (secondary stems) spaced $0.40 \mathrm{~m}$ apart. In these secondary stems, the apical meristem was removed following the development of two fruits and three leaves. The main stem emerged when the plant reached $2.0 \mathrm{~m}$ in height.

Lettuce was harvested at 58 days after transplantation (DAT) in the first and second cropping seasons. For cucumber, the growing and harvesting (every two days) periods lasted 83 and 47 days in the first cropping season and 86 and 54 days in the second cropping season, respectively.

Lettuce plants were weighed on a precision scale to determine total fresh weight (TFW) and the fresh weight of plants located on the internal (FWIP) and external (FWEP) rows of the bed. For cucumber, the following parameters were recorded: total number of fruits (TNF), number of commercial fruits (NCF), number of twisted fruits (NTF), total yield (TY), commercial yield (CY), and twisted fruit yield
(TFY). Total yield (TY) corresponded to the sum of the weights of commercial (class 20), twisted (with inclination angle greater than $30^{\circ}$ ), and noncommercial (more than $30 \mathrm{~cm}$ long or physically damaged) fruits. The weights of class 20 and twisted fruits were combined to estimate CY. To obtain the yield, the cucumber populations of 2.2 and 1.1 plants $\mathrm{m}^{-2}$, corresponding to treatments with two and one cucumber row, respectively, were considered.

Land use efficiency (LUE) was calculated using the formula proposed by WILLEY (1979): $\mathrm{LUE}=\left(\mathrm{Yc}^{\mathrm{i}}\right) /\left(\mathrm{Yc}^{\mathrm{m}}\right)+\left(\mathrm{Yl}^{\mathrm{i}}\right) /\left(\mathrm{Yl}^{\mathrm{m}}\right)$, where $\mathrm{Yc}^{\mathrm{i}}$ is the yield of cucumber intercropped with lettuce, $\mathrm{Yc}^{\mathrm{m}}$ is the yield of cucumber in monoculture, $\mathrm{Yl}^{\mathrm{i}}$ is the yield of lettuce intercropped with cucumber, and $\mathrm{Yl}^{\mathrm{m}}$ is the yield of lettuce in monoculture. The LUE index was obtained using total lettuce yield $\left(\mathrm{g} \mathrm{m}^{-2}\right)$ and total cucumber yield $\left(\mathrm{kg} \mathrm{m}^{-2}\right)$.

Data were subjected to joint analysis of variance of the experiments by the $\mathrm{F}$ test $(\alpha \leq 0.05)$. Regression analyses were performed for the factor lettuce transplanting time, where the best fit was defined based on the combination of significance and highest coefficient of determination. To verify the difference between the intercropped treatments combined with the cropping seasons and the cucumber population densities, a test for comparison of means between experiments was performed, applying the Tukey test $(\mathrm{p} \leq 0.05)$. The statistical program AgroEstat was used in all analyses (BARBOSA; MALDONADO JÚNIOR, 2015).

\section{RESULTS AND DISCUSSION}

\section{Cucumber}

For cucumber, no significant interaction was observed between experiments (cropping season and population density) and treatments (four intercropping systems and one monoculture) for TY, CY, TFY, TNF, NCF, and NTF. Also, there was no effect of treatments on these characteristics, which indicates similarity in the results obtained with cucumber in monoculture and intercropped with lettuce, regardless of lettuce transplanting time. Lettuce cropping system and transplanting time did not affect cucumber yield components (TY, CY, TFY, TNF, NCF, and NTF). The cucumber has a vertical architecture (when trained), larger size, and higher growth rate than lettuce, characteristics that allow it to quickly occupy a higher vertical space than lettuce, with consequences for competition for light in relation to shorter crops, as also observed when it was intercropped with garlic (XIAO et al., 2013). On the other hand, lettuce, with its slow growth, small size, and horizontal architecture, is less competitive than cucumber, a fact also observed when it was intercropped with other species that have characteristics similar to cucumber, such as 
pepper (REZENDE et al., 2006), tomato (CECÍLIO FILHO et al., 2011), and broccoli (OHSE et al., 2012).

Among the experiments, there was a significant difference, in which yield components were affected by the cropping season and/or cucumber population density (Table 2). The best TY and $\mathrm{CY}$ were obtained in intercropping systems established in February. The two highest TY (9.7 and $10.2 \mathrm{~kg} \mathrm{~m}^{-2}$ ) did not differ according to cucumber population density, whereas the highest CY $(10.8 \mathrm{~kg}$ $\mathrm{m}^{-2}$ ) was obtained at the lowest cucumber density (Table 2). The results obtained for TNF and NCF were similar to those observed for TY and CY, with the best values being observed in experiment 4
(1R06), associated with high values of TY and CY and a low number of twisted fruits (NTF) (Table 2). The better cucumber performance in the second season was related to the occurrence of air temperatures closer to those suitable for the growth and development of the crop. The average air temperature in the second season, from February to May 2006, was $23.7^{\circ} \mathrm{C}$, within the range of 20 to 25 ${ }^{\circ} \mathrm{C}$ established as ideal by Sganzerla (1991). From August to November 2005 (first season), in turn, the temperature averaged $27.1^{\circ} \mathrm{C}$, thus being higher than the ideal one. During this period, the maximum temperatures were always above $30{ }^{\circ} \mathrm{C}$, harming the appearance of female flowers and affecting fruit production (FONTES; PUIATTI, 2005).

Table 2. Total yield (TY), commercial yield (CY), twisted fruit yield (TFY), total number of fruits (TNF), number of commercial fruits (NCF), number of twisted fruits (NTF) of 'Hokushin' cucumber as function of experiments.

\begin{tabular}{|c|c|c|c|c|c|c|}
\hline Experiment & TY & $\mathrm{CY}$ & TFY & TNF & $\mathrm{NCF}$ & NTF \\
\hline & \multicolumn{3}{|c|}{--------------------- kg m ${ }^{-2}$----------------- } & \multicolumn{3}{|c|}{----------- Number per plant ${ }^{-1}$--------------- } \\
\hline $1-2 \mathrm{R} 05$ & $8.26 b^{1}$ & $5.75 \mathrm{c}$ & $1.47 \mathrm{a}$ & $19.57 \mathrm{c}$ & $14.34 \mathrm{c}$ & $3.45 \mathrm{a}$ \\
\hline $2-1 \mathrm{R} 05$ & $4.92 \mathrm{c}$ & $3.56 \mathrm{~d}$ & $1.00 \mathrm{~b}$ & $21.53 \mathrm{cb}$ & $16.01 \mathrm{c}$ & $3.99 \mathrm{a}$ \\
\hline $3-2 \mathrm{R} 06$ & $9.68 \mathrm{a}$ & $9.21 \mathrm{~b}$ & $0.39 \mathrm{c}$ & $21.71 \mathrm{cb}$ & $20.33 b$ & $1.23 \mathrm{c}$ \\
\hline $4-1 \mathrm{R} 06$ & $10.23 \mathrm{a}$ & $10.79 \mathrm{a}$ & $0.53 \mathrm{c}$ & $37.85 \mathrm{a}$ & $35.01 \mathrm{a}$ & $2.41 \mathrm{~b}$ \\
\hline
\end{tabular}

${ }^{1}$ Means in the column followed by different letters differ significantly among the experiments by Tukey test $(p \leq$ 0.05). 1 - 2R05: Two rows, August to November, 2005; 2 - 1R05: One row, August to November, 2005; 3 - 2R06: Two rows, February to May, 2006; 4 - 1R06: One row, February to May, 2006.

\section{Lettuce}

The total fresh weight (TFW) and the fresh weight of internally (FWIP) and externally located (FWEP) lettuce plants were affected by the interaction between experiments (cropping seasons and population density) and treatments (cropping system - intercropping and monoculture - and lettuce transplanting time).

In experiment 1 (2R05), only FWEP was influenced by the interaction between cropping system and lettuce transplanting times. Delayed lettuce transplanting reduced FWEP both in the intercropping system with cucumber $\left(2.2\right.$ plants $\left.\mathrm{m}^{-2}\right)$ and in monoculture (Figure 1A). In intercropping, the maximum FWEP $\left(1712 \mathrm{~g} \mathrm{~m}^{-2}\right)$ of lettuce was obtained when the two crops were transplanted on the same day (0 DAT). In monoculture, lettuce transplanted at 0 days after transplanting (DAT) of cucumber showed a FWEP (3586 $\mathrm{g} \mathrm{m}^{-2}$ ) 24\% higher than that of lettuce transplanted at 30 days after transplanting (DAT) of cucumber $\left(2898 \mathrm{~g} \mathrm{~m}^{-2}\right)$ (Figure 1A).

Among the cropping systems, FWEP was always higher in lettuce grown without cucumber, regardless of lettuce transplanting time (Figure 1A).
When lettuce was transplanted at 0 DAT of cucumber, the FWEP of lettuce in monoculture was $109 \%$ higher than that obtained with intercropping. For the other transplant times, the later the lettuce was transplanted, the greater the difference in FWEP between cropping systems.

Lettuce intercropped with cucumber, grown from August to November (2R05) and transplanted at 10,20, and 30 DAT of cucumber, showed twisted leaves and no head, i.e. noncommercial characteristics. Only lettuce plants transplanting at 0 DAT of cucumber were considered commercial among those intercropped with cucumber in this season. However, of the lettuce intercropped with cucumber at the lower population density, between August and November (1R05), all plants were commercial, regardless of transplanting time $(0,10$, 20, and 30 DAT of cucumber).

Lettuce TFW and FWIP in Experiment 1 (2R05) were affected only by cropping system and lettuce transplanting time. TFW and FWIP decreased linearly with the delay in lettuce transplanting time compared to that of cucumber, decreasing by $29 \%$ and $28 \%$, respectively, at 30 DAT of cucumber compared to transplanting of both on the same day (0 DAT) (Figure 1A). 

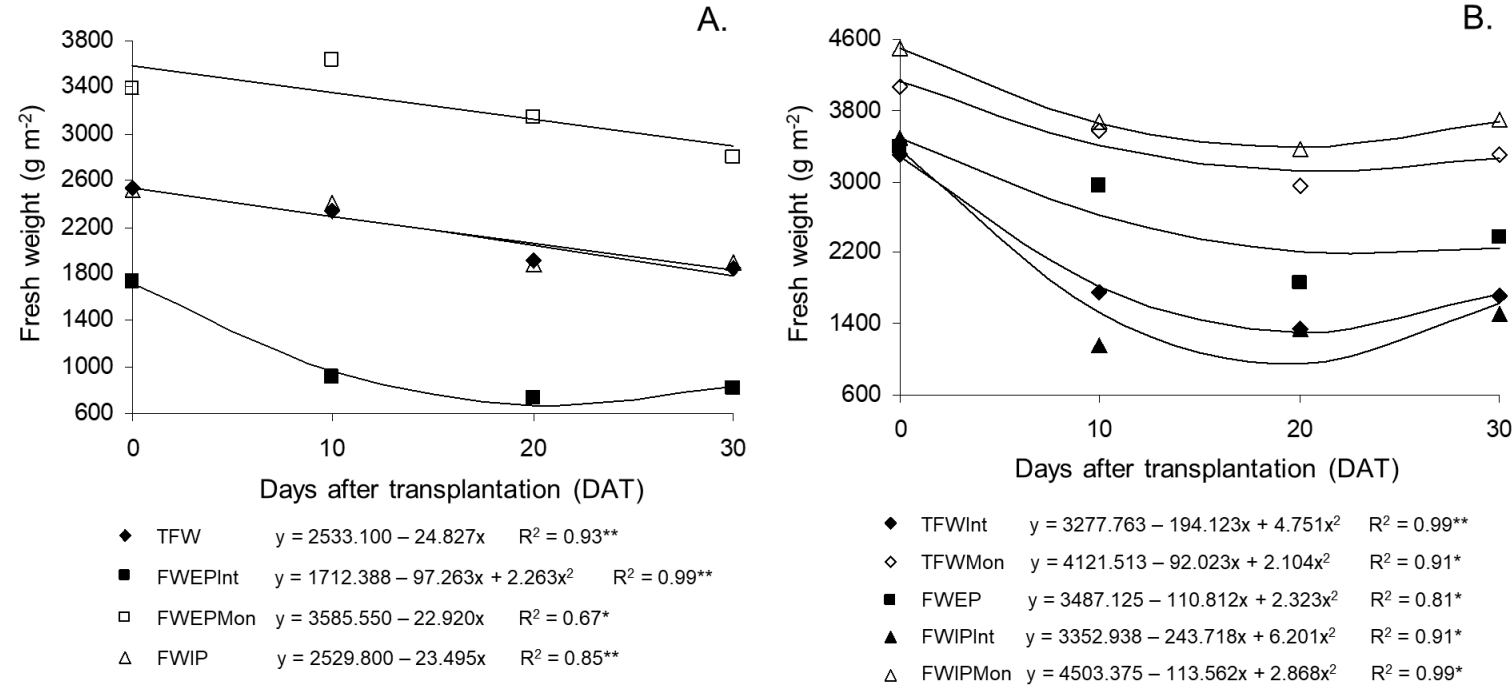

Figure 1. 'Lucy Brown' lettuce yield in intercropping (Int) and in monoculture (Mon) as function of its transplant time in relation to cucumber at experiment $1-2 \mathrm{R} 05$ : Two rows, August to November, 2005 (A) and experiment 2 - 1R05: One row, August to November, 2005 (B). TFW: Total fresh weight; FWIP: fresh weight of plants located on the internal rows of the bed; FWEP: fresh weight of plants located on the external rows of the bed.

Among the cropping systems, the highest lettuce TFW (3402 $\left.\mathrm{g} \mathrm{m}^{-2}\right)$ and FWIP $\left(3562 \mathrm{~g} \mathrm{~m}^{-2}\right)$ were obtained in monoculture, being $270 \%$ and $350 \%$ higher, respectively, than in intercropping systems.

In experiment 2 (1R05), cropping system and lettuce transplanting time influenced TFW and FWIP. Lettuce intercropped with cucumber showed similar TFW and FWIP, but when transplanted late, its TFW and FWIP decreased by $60.5 \%$ and $71.4 \%$, respectively, compared to lettuce transplanted on the same day as cucumber (Figure 1B). Although the reductions in lettuce fresh weight with delayed transplanting were significant, no detrimental effect was observed on other commercial characteristics of the plants, which allowed them to be considered commercial. Therefore, it is noteworthy that the less dense cucumber population (1.1 plants $\left.\mathrm{m}^{-2}\right)$ made it possible to obtain commercial 'Lucy Brown' lettuce plants even in an intercropping system in which lettuce was transplanted at $30 \mathrm{DAT}$ of cucumber.

Lettuce grown in monoculture produced better results than those observed in the intercropping systems, despite reductions of $24.4 \%$ in TFW and $25 \%$ in FWIP up to 22 and 20 DAT of cucumber, respectively (Figure 1B). These reductions, compared to the maximum observed at 0 DAT, were smaller than the reductions found in intercropping systems.

For lettuce FWEP, there was no interaction between cropping system and lettuce transplanting time, but it was influenced by the isolated factors. The response of FWEP as a function of lettuce transplanting time was fitted to a quadratic model, with the maximum value of $3487 \mathrm{~g} \mathrm{~m}^{-2}$ obtained for lettuce and cucumber transplanted on the same day, and an estimated minimum of $2.166 \mathrm{~g} \mathrm{~m}^{-2}$ when transplanting was carried out at 24 DAT of cucumber, with a $38 \%$ reduction in FWEP (Figure 1B). On the other hand, the FWEP of lettuce in monoculture $\left(3152 \mathrm{~g} \mathrm{~m}^{-2}\right)$ was $44 \%$ higher than that observed in the intercropping systems.

In experiment 3 (2R06), lettuce TFW, FWIP, and FWEP were influenced by the interaction between cropping system and lettuce transplanting time. Lettuce plants intercropped with cucumber at the higher population density showed a decrease in TFW, FWIP, and FWEP when lettuce transplanting was late, with reductions of $75 \%, 84 \%$, and $86 \%$, respectively, when transplanted at 30 DAT of cucumber (Figure 2A).

For lettuce in monoculture, TFW, FWIP, and FWEP were highest at 17,18 , and 17 DAT of cucumber, respectively (Figure 2A). Transplanting times after these (30 DAT of cucumber) led to a reduction of $11 \%$ in TFW, $16 \%$ in FWIP, and $7 \%$ in FWEP. However, these reductions in lettuce fresh weight when grown in monoculture were lower than those observed in intercropped lettuce. In fact, among the cropping systems, the best results were obtained in monoculture. When lettuce transplanting was carried out at 0 DAT of cucumber, the TFW of intercropped lettuce was $66 \%$ lower than that obtained in monoculture.

Lettuce intercropped with cucumber at a density of 1.1 plants $\mathrm{m}^{-2}$ in the second cropping season (experiment 4 - 1R06), was significantly affected by the interaction between cropping system and lettuce transplanting time. Late lettuce transplanting in the intercropping system promoted a decrease in TFW, FWIP, and FWEP, with the highest reductions $(72 \%, 71 \%$, and $83 \%$, respectively) being observed when transplanting was carried out at 30 DAT (Figure 2B). 

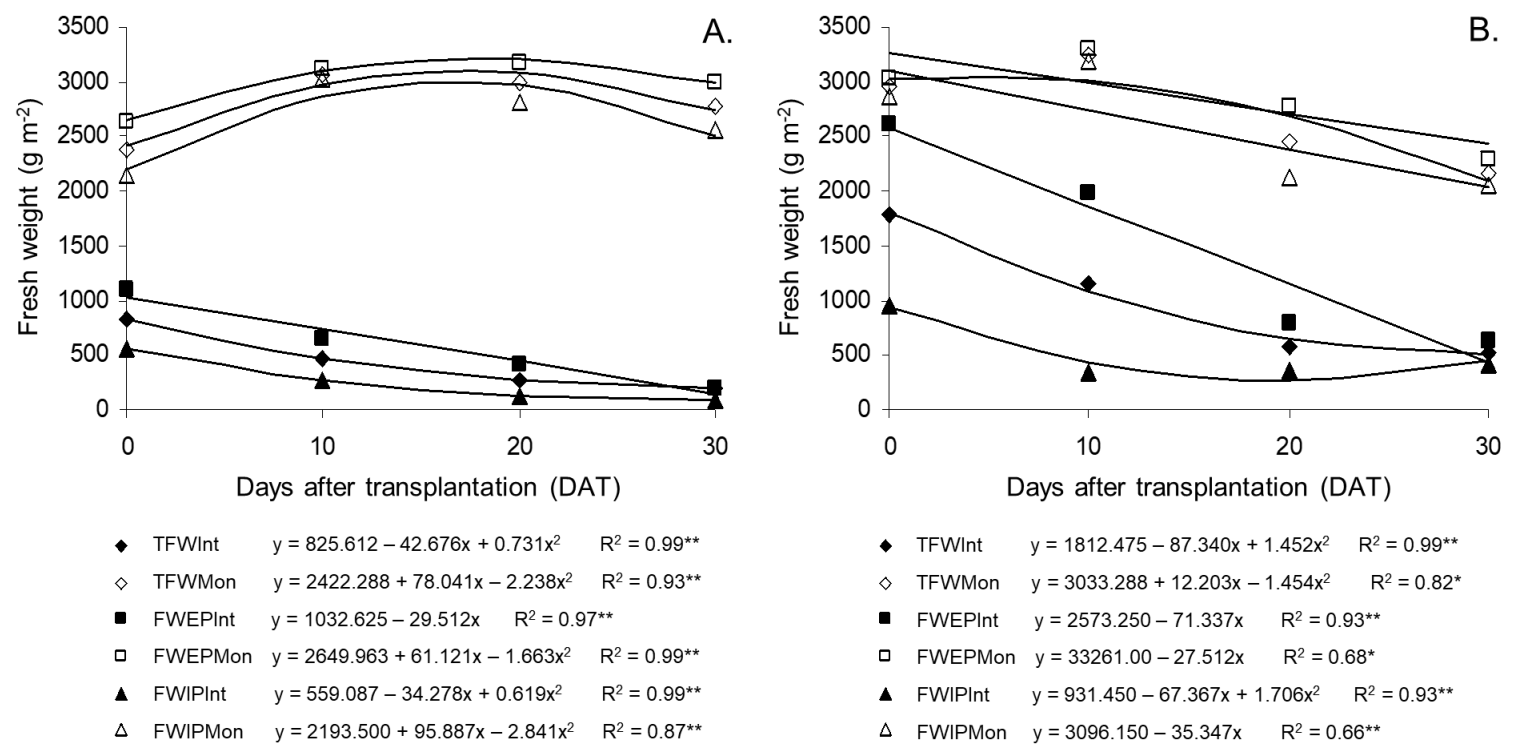

Figure 2. 'Lucy Brown' lettuce yield in intercropping (Int) and in monoculture (Mon) as function of its transplant time in relation to cucumber at experiment 3-2R06: Two rows, August to November, 2006 (A) and experiment 4 - 1R06: One row, August to November, 2006 (B). TFW: Total fresh weight; FWIP: fresh weight of plants located on the internal rows of the bed; FWEP: fresh weight of plants located on the external rows of the bed.

The highest TFW (3033 $\left.\mathrm{g} \mathrm{m}^{-2}\right)$, FWIP, (3096 $\mathrm{g} \mathrm{m}^{-2}$ ), and FWEP (3261 $\left.\mathrm{g} \mathrm{m}^{-2}\right)$ of lettuce in monoculture were found when transplanting was carried out 0 DAT (Figure 2B). The later the lettuce transplanting time, the lower the fresh weight of plants. When transplanting was carried out at 30 DAT compared to 0 DAT, the TFW, FWIP, and FWEP decreased by $32 \%, 34 \%$, and $25 \%$, respectively (Figure $2 \mathrm{~B}$ ).

Regarding lettuce in monoculture, in experiments 1, 2, and 4, fresh weight production (TFW, FWIP, and FWEP) decreased with later lettuce transplanting (Figure 1A, 1B, and 2A). This can be attributed to the worse climatic conditions for lettuce with later transplanting. The period between August and November is usually characterized by a temperature increase and a lower relative humidity, which are stressful conditions for lettuce plants. During this period, there was an increase in the average air temperature inside the greenhouse, which went from $24.5{ }^{\circ} \mathrm{C}$, for lettuces transplanted at 0 DAT, to $28{ }^{\circ} \mathrm{C}$ for later transplanting times (20 and 30 DAT). It is also noteworthy that the occurrence of maximum temperatures higher than $30{ }^{\circ} \mathrm{C}$ was common, being above the ideal considered by Carvalho et al. (2013). Among the various climatic factors, temperature is the one that most influences plant development (HATFIELD; PRUEGER, 2015), affecting the speed of chemical reactions and solute transport processes. For experiment 3 (2R06), in turn, the fresh weight production of lettuce in monoculture increased up to $18 \mathrm{DAT}$, with small decreases in weight for later transplanting times (Figure 2B).

In all experiments, lettuce intercropped with cucumber showed reductions in FWT, FWIP, and
FWEP when transplanted later than cucumber (Figures 1 and 2). This result proves the dominance of the cucumber crop in the intercropping system, as found by Cecílio Filho et al. (2015), and indicates a high degree of interspecific competition with lettuce plants, mainly for light. The rapid growth of the vertically-driven cucumber and the distribution of its photosynthetic canopy above the lettuce plants caused lettuce shading, which was greater the later the lettuce transplanting time.

Thus, although the spatial complementarity between crops was high, since the crops exploited distinct parts of the intercropping niche, the temporal complementarity between crops was low and rapidly decreased with delayed lettuce transplanting, due to the lower availability of solar radiation to lettuce. According to Lima et al. (2010), lower solar radiation decreases photosynthetic activity, growth, and production. Light is usually the main factor of production competed for by intercropped crops, and may lead one of them to die (ZHU et al., 2015). Reductions in the fresh weight of lettuce plants were also observed with delayed transplanting of lettuce intercropped with tomato (CECÍLIO FILHO et al., 2011), cucumber (REZENDE et al., 2010), and broccoli (OHSE et al., 2012).

In intercropping systems established with cucumber at a density of 1.1 plants $\mathrm{m}^{-2}$, 'Lucy Brown' lettuce plants were less affected due to the lower radiation interception by cucumber leaves and, consequently, greater availability of solar radiation. These lettuce plants had a higher fresh weight than plants intercropped with more dense cucumber populations $\left(2.2\right.$ plants $\left.\mathrm{m}^{-2}\right)$, since cucumber cultivation in double rows in the bed caused greater lettuce shading. Luminosity is one of the 
environmental factors of great relevance to the photosynthetic efficiency of plants (PETTERSEN, TORRE and GISLEROD, 2010). In intercropping, light interception by the higher crop results in lower growth and yield of the shaded one (CECÍLIO FILHO et al., 2011, 2017; ZHU et al., 2015).

The LUE index was not affected by the interaction between experiments (cucumber plant density and crop season) and treatments (crop system and lettuce transplant time), but rather by the isolated effect of experiments and cropping system. In all experiments and at all times of intercropping establishment $(0,10,20$, and 30 DAT of cucumber), LUE indices were higher than 1.0, which shows the advantage of intercropping over monoculture in the amount of food produced per unit of area. Higher LUE indices mean higher amounts of food produced per unit area (WILLEY, 1979) due to the better use of resources available in the growing environment (HADIDI, SHARAIHA and DEBEI, 2011). Thus, intercropping led to greater use of resources available in the growing environment.

LUE was $1.3,1.7,1.1$, and 1.4 in experiments 1 (2R05), 2 (1R05), 3 (2R06), and 4 (1R06), respectively, regardless of the time of intercropping establishment. Therefore, to obtain the same amount of food produced in 1 hectare of each intercropping system, it would be necessary to cultivate $1.3,1.7$, 1.1 , and 1.4 hectares respectively of cucumber and lettuce in monoculture, each occupying $50 \%$ of the area.

The highest LUE indices were found in lettuce intercropped with cucumber at a density of 1.1 plants $\mathrm{m}^{-2}$, in both the first (1R05) and second (1R06) cropping season (Figure 3). In these intercropping systems, when lettuce was transplanted on the same day as cucumber the LUE was 2.0 and 1.6 in the first and second season, respectively. Thus, to obtain the same amount of food produced in 1 hectare under these growing conditions, it would be necessary to cultivate 2.0 and 1.6 hectares of cucumber and lettuce, respectively. On the other hand, transplanting of lettuce at 10,20, and 30 DAT of cucumber promoted a linear decrease in LUE indices, with the lowest values in the intercropping system with cucumber at a density of 2.2 plants $\mathrm{m}^{-2}$ in the second cropping season (2R06).
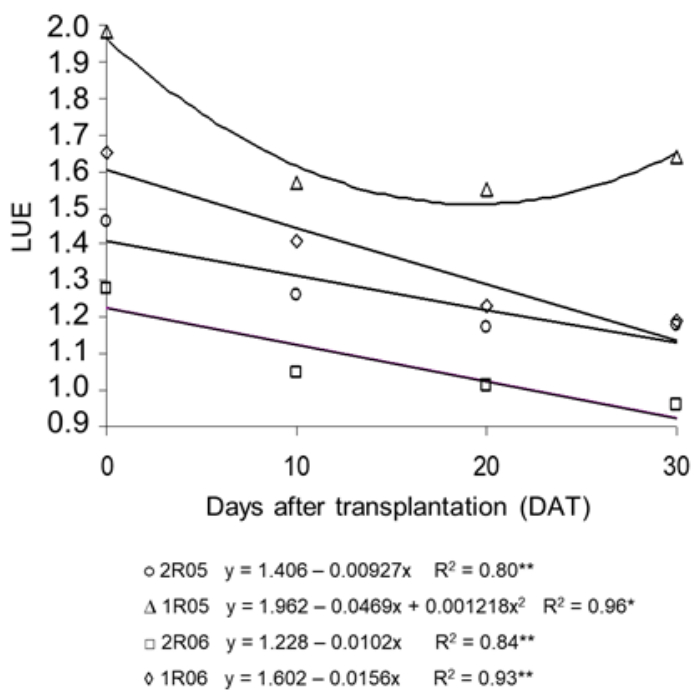

Figure 3. Land use efficiency index (LUE) for cucumber-lettuce intercroppings in the four experiments.

\section{CONCLUSION}

The results lead to the conclusion that intercropping of 'Lucy Brown' lettuce and cucumber is agronomically viable. However, it is noteworthy that the good performance obtained from the intercropping systems established from August to November (2R05 and 1R05) was not repeated at the other time of year investigated (February to May). Thus, a producer cannot expect the same crop response when establishing intercropping systems at any time. In addition, cucumber population density and lettuce transplanting time as a function of cucumber transplanting time significantly affect
LUE and the agronomic viability of intercropping.

It is recommended to intercrop 'Lucy Brown' lettuce with 'Hokushin' cucumber in the JaboticabalSP region in August and to transplant the two species on the same day. The best cucumber density for intercropping with lettuce is 1.1 plants $\mathrm{m}^{-2}$, as it allows greater availability of solar radiation to 'Lucy Brown' lettuce. The growth and yield of 'Lucy Brown' lettuce will be negatively affected by delaying its transplanting time in relation to that of cucumber. 'Lucy Brown' lettuce plants intercropped with cucumber at a density of 2.2 plants $\mathrm{m}^{-2}$ from February to May did not achieve commercial quality due to the shade provided by cucumber. 


\section{REFERENCES}

BARBOSA, J. C.; MALDONADO JÚNIOR, W. Experimentação Agronômica e Agroestat: Sistema para análises estatísticas de ensaios agronômicos. 1. ed. Jaboticabal, SP: Gráfica Multipress Ltda, 2015. 396 p.

BROOKER, R. W. et al. Improving intercropping: a synthesis of research in agronomy, plant physiology and ecology. New Phytologist, v. 206, s/n., p. 107$117,2015$.

CAI, H. et al. Effects of intercropping of garlic or lettuce with Chinese cabbage on the development of larvae and pupae of diamondback moth (Plutella xylostella). African Journal of Agricultural Research, v. 6, n. 15, p. 3609-3615, 2011.

CARVAlHO, A. D. F. et al. A cultura do pepino. 1. ed. Brasília, DF: Embrapa Hortaliças, 2013. 18 p.

CECÍLIO FILHO, A. B. et al. Agronomic efficiency of intercropping tomato and lettuce. Anais da Academia Brasileira de Ciências, v. 83, n. 3, p. 1109-1119, 2011

CECÍLIO FILHO, A. B. et al. Agronomic viability of New Zealand spinach and kale intercropping. Anais da Academia Brasileira de Ciências, v. 89, n. 4, p. 2975-2986, 2017.

CECÍLIO FILHO, A. B. et al. Indices of bioagroeconomic efficiency in intercropping systems of cucumber and lettuce in greenhouse. Australian Journal of Crop Science, v. 9, n. 12, p. 1154-1164, 2015.

FONTES, P. C. R.; PUIATTI, M. Cultura do pepino. FONTES, P. C. R. (Ed.). Olericultura: Teoria e Prática. Viçosa: Universidade Federal de Viçosa, 2005. cap. 22, p. 439-455.

GOU, F.; VAN ITTERSUM, M. K.; VAN DER WERF, W. Simulating potential growth in a relaystrip intercropping system: Model description, calibration and testing. Field Crops Research, v. 200, n. 1, p. 122-142, 2017.

HADIDI, N.; SHARAIHA, R.; DEBEI, H. Al. Effect of intercropping on the performance of some summer vegetable crops grown under different row arrangements. Scientific papers Journal Agronomy Series, v. 54, n. 2, p. 11-17, 2011.

HATFIELD, J. L.; PRUEGER, J. H. Temperature extremes: Effect on plant growth and development. Weather and Climate Extremes, v. 10, s/n., p. 4$10,2015$.
LIMA, M. A. et al. Trocas gasosas em folhas de sol e sombreadas de cajueiro anão em diferentes regimes hídricos. Revista Ciência Agronômica, v. 41, n. 4, p. 654-663, 2010.

NASCIMENTO, C. S. et al. Effect of population density of lettuce intercropped with rocket on productivity and land-use efficiency. PLoS ONE, v. 13, n. 4, p. e0194756, 2018.

OHSE, S. et al. Viabilidade agronômica de consórcios de brócolis e alface estabelecidos em diferentes épocas. Idesia, v. 30, n. 2, p. 29-38, 2012.

PETTERSEN, R. I.; TORRE, S.; GISLEROD, H. R. Effects of intracanopy lighting on photosynthetic characteristics in cucumber. Scientia Horticulturae, v. 125, n. 2, p. 77-81, 2010.

PORTO, V. C. N. et al. Combination of lettuce and rocket cultivars in two cultures intercropped with carrots. Horticultura Brasileira, v. 29, n. 3, p. 404 411, 2011.

REZENDE, B. L. A. et al. Economic analysis of cucumber and lettuce intercropping under greenhouse in the winter-spring. Anais da Academia Brasileira de Ciências, v. 83, n. 2, p. 705 $-717,2011$.

REZENDE, B. L. A. et al. Viabilidade da consorciação de pimentão com repolho, rúcula, alface e rabanete. Horticultura Brasileira, v. 24, s/ n., p. 36-41, 2006.

REZENDE, B. L. A. et al. Consórcios de alface crespa e pepino em função da população do pepino e época de cultivo. Interciência, v. 35 , n. 5, p. 374 $379,2010$.

ROLIM, G. S. Dados meteorológicos. Disponível em: $\quad$ https://www.fcav.unesp.br/\#!/estacaoagroclimatologica/resenha/. Acesso em: 08 set. 2019.

SANTOS, H. G. et al. Sistema Brasileiro de Classificação de Solos. 5. ed. Brasília, DF: EMBRAPA, 2018. 353 p.

SGANZERLA, E. Nova agricultura: a fascinante arte de cultivar com os plásticos. 4. ed. Porto Alegre, RS: Petroquímica Triunfo, 1991. 303 p.

TRANI, P. E. et al. Abobrinha ou abóbora de moita; abóbora rasteira, moranga e híbridos; bucha e pepino. In: RAIJ, B. V. et al. (Eds.). Recomendações de adubação e calagem para o Estado de São Paulo. 2. ed. Campinas: IAC, 1997. cap. 18, p. 165.

TRANI, P. E.; PASSOS, F. A.; AZEVEDO FILHO, 
J. A. Alface, almeirão, chicória, escarola, rúcula e agrião d'agua. In: RAIJ, B. V. et al. (Eds.). Recomendações de adubação e calagem para o Estado de São Paulo. 2. ed. Campinas: IAC, 1997. cap. 18 , p. 168-169.

WANG, M. et al. Soil chemical property changes in eggplant/garlic relay intercropping systems under continuous cropping. PLoS ONE, v. 9, n. 10, p. e111040, 2014.

WILLEY, R. W. Intercropping - its importance and research needs. Part 1 - Competition and yield advantage. Field Crops Abstracts, v. 32, n. 2, p. 110, 1979.

XIAO, X. et al. Intercropping of Green Garlic (Allium sativum L.) Induces Nutrient Concentration Changes in the Soil and Plants in Continuously Cropped Cucumber (Cucumis sativus L.) in a Plastic Tunnel. PLoS ONE, v. 8, n. 4, p. e62173, 2013.

ZHU, J. et al.The contribution of phenotypic plasticity to complementary light capture in plant mixtures.New Phytologist, v. 207, n. 4, p. 12131222, 2015. 